\title{
Correction to: The Role of Institutional Quality in Finance-Growth Nexus: Evidence from North African Countries
}

\section{Imen Mohamed Sghaier ${ }^{1}$}

Published online: 14 February 2022

( ) Springer Science+Business Media, LLC, part of Springer Nature 2022

\section{Correction to: Journal of the Knowledge Economy https://doi.org/10.1007/s13132-021-00850-6}

The original version of this article was published on 25 October 2021; the author has found errors in the published version of the paper. In page 3 , the remainder of this paper is organized as follows. The "Overview of Financial Development in the North African Countries" section presents a summary of the North African financial systems; then, the "Literature Review".... Another error is in Table 1, in column "North Africa" row "Number of branches," value should be 13905 not 0.13905 . Also, in the paper, there are several words that are written in Italics that should be corrected.

Original article has been corrected.

Publisher's Note Springer Nature remains neutral with regard to jurisdictional claims in published maps and institutional affiliations.

The original article can be found online at https://doi.org/10.1007/s13132-021-00850-6.

Imen Mohamed Sghaier medsghaier.imen@gmail.com

1 Higher Institute of Business Administration, University of Sfax, Sfax, Tunisia 